\title{
MEtHOdS FOR PARASITIC PROTOZOANS DETECTION IN THE ENVIRONMENTAL SAMPLES
}

SKOTARCZAK B.*

\section{Summary:}

The environmental route of transmission of many parasitic protozoa and their potential for producing large numbers of transmissive stages constitute persistent threats to public and veterinary health. Conventional and new immunological and molecular methods enable to assess the occurrence, prevalence, levels and sources of waterborne protozoa. Concentration, purification, and detection are the three key steps in all methods that have been approved for routine monitoring of waterborne cysts and oocysts. These steps have been optimized to such an extent that low levels of naturally occurring (oo)cysts of protozoan can be efficiently recovered from water. Ten years have passed since the United States Environmental Protection Agency (USEPA) introduced the 1622 and 1623 methods and used them to concentrate and detect the oocysts of Cryptosporidium and cysts of Giardia in water samples. Nevertheless, the methods still need studies and improvements. Pre-PCR processing procedures have been developed and they are still improved to remove or reduce the effects of PCR inhibitors. The progress in molecular methods allows to more precise distinction of species or simultaneous detection of several parasites, however, they are still not routinely used and need standardization. Standardized methods are required to maximize public health surveillance.

KEY WORDS : protozoa, parasite, detection, environment, 1622 and 1623 methods, PCR inhibitors, molecular methods.
Résumé : MÉTHOdes de déteCtIONS DES PROTOZOAIRES PARASITES DANS L'ENVIRONNEMENT

Les voies de transmissions de nombreux protozoaires parasites dans l'environnement et leur aptitude à y produire un nombre élevé de formes transmissibles constituent des menaces persistantes tant en santé humaine qu'animale. Des méthodes conventionnelles et de nouvelles méthodes moléculaires et immunologiques permettent d'évaluer la fréquence, la prévalence, les niveaux et les origines des protozoaires transmis par l'eau. La concentration, la purification et la détection sont les trois étapes clés de toutes les méthodes agréées pour la surveillance de routine des kystes et des oocystes transmis par l'eau. Ces étapes ont été optimisées à un niveau d'efficacité tel que les faibles concentrations naturelles $d^{\prime}$ (oo)cystes présents dans l'eau sont efficacement détectées. Dix ans se sont écoulés depuis l'introduction par l'United States Environmental Protection Agency (USEPA) des méthodes 1622 et 1623, et leur utilisation dans la concentration et la détection des oocystes de Cryptosporidium et des kystes de Giardia dans les échantillons d'eau. Néanmoins, ces méthodes requièrent toujours des compléments d'études et des améliorations. Des procédures de pré-PCR ont été développées et sont encore améliorées en vue de supprimer ou de réduire les effets des inhibiteurs de la PCR. Le progrès réalisé dans les méthodes moléculaires permet une identification plus précise des espèces ou la détection simultanée de plusieurs parasites; cependant, elles ne sont pas encore utilisées en routine et doivent être standardisées. Des méthodes standardisées sont impératives pour optimiser cette surveillance en termes de santé publique.

MOTS CLÉS : protozoaire, parasite, détection, environnement, méthodes 1622 et 1623, inhibiteurs de la PCR, méthodes moléculaires.

\section{INTRODUCTION}

$\mathrm{P}$ rogress, that was made in the last decade in the development of molecular methods detecting the DNA of pathogenic microorganisms, concerns also the parasitic protozoa. However, the majority of diagnostic methods used in the clinical practice has a limited application regarding the detection of protozoans in water samples. The most important restriction is lower concentration of cysts or oocysts in water in comparison with material collected from patients. In order to improve the monitoring of oocysts of Cryp-

\footnotetext{
* Department of Genetics, University of Szczecin, al. Piastów 40b, 71-065 Szczecin, Poland. Tel./fax: +48914442780.

E-mail: boskot@univ.szczecin.pl
}

tosporidium in water, the United States Environmental Protection Agency (USEPA) introduced the 1622 method and then 1623, which were designed for concentration and detection of Cryptosporidium oocysts and Giardia cysts in water samples. Additionally, in the environmental sample much wider range of protozoans, that can be potentially found in the studied environment, should be taken into consideration, as well as the presence of unknown interfering factors, that can hamper the course of many molecular reactions. The detection of the presence of cysts and oocysts with the molecular methods, in such material as surface water, sewage and wastewater, or faeces, is often hampered by the occurrence of organic and inorganic substances, that can potentially be inhibitors in test based on the nucleic acids. 


\section{DEVELOPMENT IN THE METHODS OF DETECTION}

\section{RECOVERY OF CRYPTOSPORIDIUM AND GIARDIA WITH THE METHODS 1622/1623}

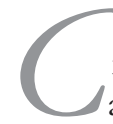

Tryptosporidium species are parasites that cause mainly enteric illnesses in humans and other animals. The transmission is most commonly waterborne, but other sources of infection, including food-borne and person-to-person spread have been documented (Leav et al., 2003). The oocyst, environmental form of the parasite, is resistant to most water purification methods, including chlorination. Cryptosporidium infection usually causes a self-limited diarrheal illness but can be life-threatening in immunocompromised individuals (Leav et al., 2003). Cryptosporidium is considered to be one of the indicators of environmental contamination and water quality (Fayer, 2004; Ramirez \& Sreevatsan, 2006). In the United States species of the Giardia genus are the most commonly diagnosed intestinal parasites and cause approximately 200 million clinical infections per year worldwide (Furness et al., 2000; Barbosa et al., 2008).

The 1622 and 1623 methods were prepared to improvesupport an estimation of the risk made for public health, caused by drinking water polluted with the protozoans such as Cryptosporidium and Giardia. In 1996, the Environmental Protection Agency (EPA) started the process of acquisition and application of the newest technologies for the detection and identification of those parasites (U.S. Environmental Protection Agency, 2001). The 1622 method for the detection of Cryptosporidium was prepared in December 1996, confirmed with the interlaboratory studies in 1998 and definitely approved at the beginning of 1999 .

Both methods are used to determine the presence and concentration of the resistant forms in water, and they consist of: filtration, concentration of oocysts, immunomagnetic separation (IMS), fluorescent antibody and 4',6'-diamidino-2-phenylindole (DAPI) counter staining, differential interference contrast (DIC), and microscopic detection and enumeration. These methods do not allow the identification of Cryptosporidium or Giardia species, as well as the origin of species, or the pathogenic potential of oocysts and cysts. Such data can be obtained with the use of one of the molecular methods based on the nucleic acids isolated from the resistant forms of these parasites, which were obtained with the discussed methods.

In both methods, the filtration of water samples of 10501 volume is carried out with the use of filters with porosity of $1 \mu \mathrm{m}$ in accordance with the producer's recommendations. The EPA approved several kinds of filters which can be used in both methods (Whatman Nucleopore CryptTest ${ }^{\mathrm{TM}}$ filtr, IDEXX Filta-Max ${ }^{\mathrm{TM}}$ filtr,
Meridian Diagnostics Merifluor Cryptosporidium/Giardia). The next step is concentration of the eluate washed out from the filter, by rotation and suction with a vaccum pump. The immunomagnetic separation (IMS) is used to separate cysts and oocysts from foreign materials. It is carried out with the use of microballs bound to the monoclonal antibodies anti-Cryptosporidium and anti-Giardia. While shaking the samples, the typical reaction antigen-antibody happens, in this case it is binding the surface antigens of cysts and oocysts by the inserted antibodies. Then, the samples are treated with the magnetic field to separate the created complexes from pollutions and the microballs (Shaw et al., 2008).

Immunofluorescence, a method that investigates the reaction antigen-antibody labeled with fluorochrome, is used to estimate the environmental forms of the discussed parasites in the microscopic picture. A result of the reaction in the form of shining complexes is either observed in the UV light or it is measured with the use of a flow cytometer. The quality analysis in the microscopic picture is based on the search of objects that comply with the specific morphological parameters: size (Giardia cysts with the diameter of 8-12 × $7 \mu \mathrm{m}$, for Cryptosporidium oocysts 4-6 $\mu \mathrm{m})$, shape (oval - Giardia cysts, spheroidal or a bit oval Cryptosporidium oocysts), and fluorescence properties characteristic for Giardia cysts and Cryptosporidium oocysts. Microscopic interpretation of the IFA-stained cysts and oocysts is a key step in the monitoring of Cryptosporidium oocysts and Giardia cysts. EPA method 1623 requires technically proficient analysts for final confirmation (U.S. Environmental Protection Agency, 2001). The identification of Cryptosporidium and Giardia contamination is thus totally dependent on the experience of the analyst. Since artificial neural networks (ANN) can provide an automated means of identification, thereby reducing human errors related to misidentification, ANN were developed to identify Cryptosporidium oocyst and Giardia cyst images (Widmer et al., 2005).

The IFA analysis should be confirmed by staining with the use of DAPI and microscopic observation in the differential-interference contrast according to Nomarski. DAPI creates the fluorescence complexes with the sequences rich in the AT pairs in the double-stranded DNA chain, and in this connection it is the method allowing a visualization of nuclei, which are visible in the oocysts in the number from 1 to 4 , stained in blue. In order to estimate the effectiveness of recovery of the environmental forms of these parasites, the quality control of samples known as matrix spike (MS) is recommended. The analysis of MS is a determinant of the effectiveness of the applied analytical procedure (Francy et al., 2004). There are two analyzed samples, the number of viable added organisms (matrix spikes) is known in 
the first one, unknown in the second one. The recovery from matrix spike is enumerate from the simple formula:

$$
\frac{A_{m s}-A_{f s}}{A_{a}} \times 100
$$

$\mathrm{A}_{\mathrm{ms}}=$ the amount of obtained organisms in the matrix spike sample.

$\mathrm{A}_{\mathrm{fs}}=$ the amount of obtained organisms in the field sample.

$\mathrm{A}_{\mathrm{a}}=$ the amount of added organisms.

As it was defined in the 1623 method, the matrix spikes are required for every $20^{\text {th }}$ sample or when a new source of water is investigated. Francy et al. (2004) took into consideration the MS for every analyzed sample. They discovered, that in some cases, the recoveries between two samples collected from the same place were completely different, especially when turbidities of the water samples were different. Furthermore, it turned out that while determining an average recovery in some samples, concentrations of the environmental oocysts had been increasing significantly above those enumerated without the possibility of determination of the average recovery. The determination of the effectiveness of recovery provides also data for the enumeration of the detection limits. In this study, a wide range of the detection limits for different samples and places of collection has been appointed. Therefore, the authors emphasize that it seems reasonable to bring the MS procedure, not only when a new source of water is investigated, but also when the samples are collected in different streams of flowing water or at different turbidity than those samples collected earlier and investigated from the same place. Both methods allow to replace components with others more efficient or effective, provided that they comply with the criteria of quality control (Francy et al., 2004). And so, different filter systems are applied for the filtration required in these methods. As it turned out, the efficiency of those methods, assessed in practice, shows different degrees of recovery of cysts and/or oocysts depending on the applied filter system (Wohlsen et al., 2004). These and many other studies show that these methods have got many restrictions. The most important one is different efficiency of the recovery. The other restriction is that the 1623 method does not give a possibility to estimate the viability and infectivity of the detected oocysts, as well as the Cryptosporidium species. A logistic limitation is another restriction (degradation of oocysts during transfer), especially in the method, and finally the state of the science of Cryptosporidium testing in general (Weintraub, 2006). Because the 1623 method is commonly used to monitor sources of drinking water and is the required method in the programme of surface water treatment, the modifications for the improvement of recovery and reduction of analytical costs are needed (Francy et al., 2004; Weintraub, 2006).
EXTRACTION OF DNA FOR THE MOLECULAR METHODS. EFFECTIVITY OF THE DNA ISOLATION AND INHIBITORS IN THE ENVIRONMENTAL SAMPLES THAT AFFECT THE PCR RESULT

For environmental samples, the efficiency of DNA extraction methods is determined by the DNA recovery rate and PCR (polymerase chain reaction) inhibitor reduction during DNA extraction. Many studies have shown that PCR inhibitors occurring in water samples suppress or reduce PCR amplification (Johnson et al., 1995; Loge et al., 2002). The environmental samples (water, soil, and food) are rich in PCR inhibitors, such as humic acids, potassium dichromate, formaldehyde which could be co-extracted with DNA during the DNA isolation and purification process and which therefore could interfere with the PCR amplification (Tebbe \& Vahjen, 1993). As shown by studies of Guy et al. (2003), phenols are important substances that reduce the PCR amplification. Phenols in the aquatic environments come from natural sources, such as biodegradation of humic substances, lignins and tannins, and from manmade sources, such as derivatives of plastics and degradation of pesticides and herbicides (Bruzzoniti et al., 2000). The applied herbicides may be an alternative source of the phenol-containing inhibitors.

Reduction or removal of PCR inhibitors are essential components in the molecular detection of microorganisms in environmental samples (Wilson, 1997). Reduction or elimination of PCR inhibitors prior to, during, or after DNA extraction has become an important stage in molecular diagnosis of protozoan pathogens in water and other environmental samples (Jiang et al., 2005). Currently, Cryptosporidium and Giardia by IMS and culture enrichment prior to DNA extraction are standard procedures to eliminate or considerably reduce substances that might be inhibitory to DNA amplification by PCR (Lowery et al., 2001; Nugent et al., 2001; Fontaine \& Guillot, 2003). These, however, become impractical for organisms that have no IMS procedures or that cannot be cultured. The use of IMS is also expensive, and this limits the use of samples mostly to single-organism detection (Jiang et al., 2005). However, IMS is not only expensive; its performance is affected by the type of commercial kits used, $\mathrm{pH}$, and dissociation procedures (Ware et al., 2003). Thus, the development of methods for direct extraction of PCR quality DNA is very significant for the detection of pathogens in environmental samples.

\section{DEVELOPMENT OF PROCEDURES FOR DIRECT EXTRACTION OF CYSTS AND OOCYSTS DNA FROM WATER CONCENTRATES OF PCR INHIBITORS}

Because samples of water have only a few Cryptosporidium oocysts in the presence of many other microorganisms, the recovery of Cryptosporidium DNA during 
DNA extraction is very important. Numerous direct DNA extraction methods have been tested in the preparation of DNA from Cryptosporidium spp., such as phenol-chloroform extraction method and the use of the commercial FastDNA SPIN kit for soil, QIAamp DNA stool minikit, QIAamp DNA minikit and UltraClean soil kit. Despite most of these methods were used for the extraction of DNA from human or animal fecal specimens, the detection of Cryptosporidium oocysts in water samples by these direct DNA extraction methods was adapted.

Methods of DNA extraction from Cryptosporidium oocysts and Giardia cysts were evaluated and compared for example by Guy et al. (2003). The DNeasy kit (Qiagen) system (including proteinase K) was chosen as a rapid method and provides an inexpensive means of cleaning up the DNA from contaminates. Comparison of DNA extraction methodologies to maximize DNA yield from cysts and oocysts determined that a combination of freeze-thaw, sonication, and purification using the DNeasy kit (Qiagen) provided a highly efficient method. To detect the presence of inhibitors, the PCR mixtures containing the environmental water sample extracts were spiked with 500 pg of G. lamblia DNA, and DNA was detected using P241 in the qPCR assay. The cycle threshold values from qPCR were compared to those obtained from the same concentration of DNA that was spiked into the PCR mixture containing water only. They noted that DNA extracts obtained from samples of pond or river water were fully inhibitory to qPCR. The addition of BSA (final concentration, $20 \mathrm{ng} / \mathrm{\mu l}$ ) to the PCR mixture removed the inhibitory effect.

In the study of Jiang et al. (2005), the efficiencies of these all DNA extraction methods for the detection of Cryptosporidium with oocyst-seeded samples, DNAspiked samples, and field water samples were evaluated. The evaluation was conducted on the basis of the presence or absence of PCR product of the ssu rRNA gene of Cryptosporidium. The results of studies demonstrated that PCR inhibitors were present in all DNA solutions extracted by all these methods. However, the effect of PCR inhibitors could be reduced significantly by $400 \mathrm{ng}$ of bovine serum albumin BSA/ $\mu \mathrm{l}$ or $25 \mathrm{ng}$ of T4 gene 32 protein/ $\mu$ lo the PCR mixture. With the inclusion of bovine serum albumin in the PCR mixture, DNA extracted with the FastDNA SPIN kit for soil without oocyst isolation resulted in PCR performance similar to that generated by the QIAamp DNA minikit after oocysts were purified by IMS. The authors concluded that direct DNA extraction with the FastDNA SPIN kit for soil in combination with the use of a high concentration of BSA represents an effective tool for PCR detection of Cryptosporidium oocysts in water samples. This technique lowers the cost of current PCR detection of Cryptosporidium oocysts in water samples significantly and enables the use of extracted DNA for the analysis of other pathogens. It may also facilitate the development of detection methods for pathogens that have no IMS isolation (Jiang et al., 2005).

Two oocyst recovery methods, sodium chloride and sucrose flotation techniques were compared by Ramirez \& Sreevarson (2006). Two commercial DNA extraction kits (Stool Kit QIAGEN, Inc., Valencia, CA; UltraClean ${ }^{\mathrm{TM}}$ Mega Soil DNA Kit, Mo Bio Laboratories, Inc., Carlsbad, CA) were performed using feces, soil and water samples each inoculated with different concentration of Cryptosporidium oocysts. Subsequently, methods were used to test field samples. The second was able to detect above $1 \times 10^{6}$ oocysts. The sucrose flotation method provided the greatest analytical sensitivity detecting as few as 10 oocysts. The PCR-hybridization detection limit was 10 oocysts for feces and soil, and less than 10 oocysts for water samples.

For the detection of other protozoans, modifications of methods for DNA extraction and purification of DNA after DNA extraction have also been tested to remove PCR inhibitors by treatment with Chelex 100 (Guy et al., 2003) or polyvinylpyrrolidone (da Silva, 1999; Guy et al., 2003) or by chemical flocculation (Braid et al., 2003) during DNA extraction and by purification of DNA with anti-inhibitory substances (Kramer et al., 2002) and chromatography (Tebbe \& Vahjen, 1993) after DNA extraction. In many studies BSA, T4 gene 32 protein and polyvinylpyrrolidone have been used to remove the effects of PCR inhibitors during the PCR assay.

Goldschmit et al. (2008) studied the implication of the DNA extraction procedures in the detection of Acanthamoeba. Acanthamoeba cysts mixed with a tag virus were processed according to different DNA preparation procedures of many commercial DNA extraction kits. Parasite-DNA loads were assessed by real-time PCR. The results of studies show that the cysts of Acanthamoeba are resistant to reagents releasing the DNA from other cells and viruses. Heat, $\mathrm{NaOH}$ or ProtK did not allow the DNA extraction yields to be assessed or the inhibitors to be eliminated. The QIAmp and the MagNA Pure improved the sensitivity of the PCR and eliminated the inhibitors partially only. A significant increase in extraction was obtained with a ProtK treatment before commercial extraction kits. ProtK + MagNA Pure yielded the highest rates of positivity. The authors concluded that to minimize false negative results, the nucleic-acid based on Acanthamoeba diagnosis requires the efficient lysis of cysts (without affecting the DNA) to make the DNA available for extraction and the elimination of PCR inhibitors.

\section{MOLECULAR METHODS FOR DETECTION}

Molecular methods are useful for monitoring anthropogenic viral, bacterial and protozoan enteropatho- 
gens, and to track pathogen specific markers in a complex environment in order to reveal sources of these agents (Graczyk \& Conn, 2008). Usually, the choice of an assay and molecular marker mainly depends on the amount of information carried by the genetic locus under analysis. Some assays allowed to distinguish between isolates of the same species (genotypes), while others can be used to identify the different species within a genus, and some can even be used for both aims. A variety of PCR assays have been described for Cryptosporidium, Giardia and for some other waterborne protozoans. The analysis after PCR are usually based on the direct sequencing of the amplification products, or on the digestion with enzymes followed by gel electrophoresis of the restriction fragments (RFLP). The progress in molecular methods allows a more precise differentiation between species (nested PCR) or simultaneous detection of several parasites (multiplex PCR). Moreover, with the recent introduction of real-time PCR, that provides the continuous monitoring of amplicon formation throughout the reaction, quantitative aspect of the infection could be studied with perfect sensitivity. This assay enables to detect carrier states and to determine the number of (oo)cysts present in a sample, because it is possible to assess here the early concentration of DNA template and estimate the number of genomes in the sample. Reverse transcription real-time PCR gives the opportunity to study quantitative aspects of gene expression during the different phases of the infection. Additionally, real-time PCR is a very attractive methodology for laboratory diagnosis of infectious diseases because of its characteristics that eliminates post-PCR analysis, leading to shorter times, a reduction in the risk of amplicon contamination of laboratory environments, and reduced reagent costs (Klein, 2002).

\section{NeSTED MUltipleX PCR ASSAY FOR DifFERENTIAL DETECTION OF ENTAMOEBA HISTOLYTICA, E. MOSHKOVSKII AND E. DISPAR}

E. histolytica, a pathogenic amoeba, is indistinctive in its cyst and trophozoite stages from those of nonpathogenic E. moshkovskii and E. dispar by light microscopy. Currently a few commercial ELISA kits are available for detection of E. histolytica/E. dispar coproantigen in stool. Some ELISA kits have been designed to specifically identify $E$. histolytica

Among molecular methods, a nested PCR targeting 16Slike rRNA gene has been reported to detect and differentiate E. histolytica, E. dispar and E. moshkovskii directly in stool specimens. (Ali et al., 2003; Parija et al., 2005). But the identification of the amoeba either as E. histolytica, E. dispar or E. moshkovskii was carried out by performing nested PCR each time separately for individual species which was tedious. To avoid this disadvantage, the aim of the study of Khainar \& Parija (2007) was to develop and evaluate a nested multiplex PCR targeting the 16S-like rRNA gene for simultaneous detection and differentiation of E. histolytica, E. moshkovskii and E. dispar directly in stool samples. The species specific product size for $E$. histolytica, E. moshkovskii and E. dispar was 439, 553 and 174 bp respectively, thus clearly different for all that three species. The method showed a sensitivity of $94 \%$ and specificity of $100 \%$ for the demonstration of E. histolytica, E. moshkovskii and E. dispar DNA in stool samples. Moreover, this study showed that only $34.6 \%$ of the patient stool samples that were positive for E. histolytica/E. dispar/E. moshkovskii by examination of stool by microscopy and/or culture, were actually positive for pathogenic E. histolytica and the remaining majority of the stool samples were positive for nonpathogenic E. dispar or E. moshkovskii. The authors conclude, that this study reports a new strategy for species specific detection and differentiation of $E$. histolytica, E. dispar and E. moshkovskii and it is also rapid, providing the results within 12 hours of receiving stool specimens. Thus, in the nearest time, we can expect the application of this protocol for water samples.

\section{MULTIPLEX REAL-TIME PCR FOR DETECTION OF ENTAMOEBA HISTOLYTICA, GIARDIA INTESTINALIS, AND CRYPTOSPORIDIUM SPP.}

The three major waterborne protozoan diseases are cryptosporidiosis, giardiasis and amoebiasis (Bouzid et al., 2008). E. histolytica, G. intestinalis and Cryptosporidium spp. are not only three of the most important and common diarrhea-causing parasitic protozoa. Microscopic diagnosis of these parasites is neither sensitive nor specific. Recently, more specific and sensitive alternative molecular methods (PCR and antigen detection tests) have been introduced for all three of these parasitic infections. However, in a routine diagnostic laboratory, parasite-specific methods for diagnosis of each of the infections are time consuming and increases the cost of examination (Haque et al., 2007). Recently, the real-time PCR, a new methodology that uses fluorescent labels to enable continuous monitoring of amplicon (PCR product) formation throughout the reaction, has been adapted to detect these parasites and reported in the literature (Roy et al., 2005; Amar et al., 2003, Guy et al., 2003; Verweij et al., 2004). In the study of Haque et al. (2007), a Taqman-based multiplex real-time PCR assay has been designed and evaluated to diagnose these three important protozoan parasites in one reaction. They targeted oocyst wall protein gene instead of the rRNA gene for Cryptosporidium because they wanted to have similar annealing temperature of all the primers that were used in this 
study. This assay developed for three parasites can be easily used for two (e.g. G. intestinalis and Cryptosporidium spp.) only. In earlier studies carried out by Verweij et al. (2004) with well-defined DNA and stool samples as controls, the multiplex real-time assay for the detection of E. histolytica, G. lamblia, and Cryptosporidium spp. were effective. In all samples tested in which microscopy revealed the presence of E. histolytica, G. lamblia, or C. paruum, specific amplification was detected. There was no difference in the performance of the amplification of the specific targets in the individual assays compared with the multiplex PCR, so the multiplex PCR was as reliable as the individual assays concluded the authors. This technique seems very useful for the simultaneous identification of different pathogens, but still needs standarization.

\section{Multiplex Real-Time PCR assay FOR GenOtyPe- SPECIFIC DETECTION OF GIARDIA LAMBLIA}

The genus Giardia can be differentiated on the basis of morphology, ultrastructural features, or $18 \mathrm{~S}$ rRNA gene sequence into six species, G. lamblia (synonymous with G. duodenalis or G. intestinalis), G. agilis, G. muris, G. ardeae, G. psittaci, and G. microti (Monis et al., 1999). Isolates of G. lamblia have been further subgrouped by alloenzyme or sequence analysis of the 18S rRNA, glutamate dehydrogenase, triose phosphate isomerase, elongation factor $1 \alpha$, and other genes. Depending on the assay, G. lamblia subgroup nomenclature has included Nash groups 1 to 3, genotype "Poland" versus "Belgium", and assemblages A and B with subgroups A-I, A-II, B-III, and B-IV ( $\mathrm{Ng}$ et al., 2005). Phylogenetic sequence analysis of the independent genetic loci has provided essentially coincident results that there are two major G. lamblia groups which cause human infection (Monis et al., 1999). Therefore, the population genetics of this organism should be re-evaluated to take into account the effect of recombination among members of the $G$. duodenalis species complex (Caccio \& Ryan, 2008). Ng et al. (2005) developed a multiplex real-time PCR assay utilizing self-probing amplicon primers that would distinguish assemblages A and B in a single reaction. The assay utilized Scorpion probes that combined genotype-specific primers and probes for the 18S rRNA gene into the same molecule. The protocol was capable of detecting as few as 20 trophozoites per PCR on fecal DNA isolated using a commercial method (QIAamp DNA Stool Mini kit) or 1.25 trophozoites per PCR on fecal DNA isolated using a G. lamblia-specific oligonucleotide capture technique. Authors conclude, that this single-reaction multiplex qPCR analysis distinguishes assemblage A Giardia infections from assemblage B infections directly on fecal samples and may aid epidemiologic investigation.
DEVELOPMENT IN CRYPTOSPORIDIUM GENOTYPING TO TRACK THE SOURCES OF CRYPTOSPORIDIUM OOCYST CONTAMINATION IN WATER

Because oocysts of all Cryptosporidium spp. are morphologically similar and have the potential to be present in water, sensitive and specific detection and typing of Cryptosporidium oocysts in water are essential for risk assessment. PCR-based methods have been used increasingly for detection and analysis of Cryptosporidium oocysts in water, and unlike methods 1622 and 1623, the more recent PCR methods (e.g. genotyping techniques) can differentiate Cryptosporidium species pathogenic fort humans from those non-pathogenic. Although many surface water samples contain Cryptosporidium oocysts, it is unlikely that all these oocysts belong to human-pathogenic species or genotypes, because only a few genotypes of Cryptosporidium parasites (e.g. the C. parvum human and bovine genotypes, C. meleagridis, C. canis, and C. felis) are responsible for most human infections (Xiao et al., 2004; Yang et al., 2008). Information on the source of C. parvum contamination is necessary for effective evaluation and selection of management practices for reducing $C$. parvum contamination of surface water and the risk of cryptosporidiosis. Because most Cryptosporidium species and genotypes are host specific, genotyping techniques are also used for tracking sources of contamination. One tool, a small-subunit (SSU) rRNA gene-based PCR-restriction fragment length polymorphism (RFLP) technique, has been used effectively for genotyping Cryptosporidium oocysts in surface water, storm water, and wastewater samples (Xiao et al., 2004; Ruecker et al., 2007; Yang et al., 2008). These studies indicated that mature cattle were probably the main source of contamination of the watershed and gentotyping showed that most of Cryptosporidium species and genotypes did not carry the risk for humans.

\section{CONCLUSION}

oncentration, purification, and detection are the
three key steps in all methods that have been
approved for routine monitoring of waterborne cyst and oocysts. These steps have been optimized to such an extent that low concentration of naturally occurring (oo)cysts of protozoan can be efficiently recovered from water. Although ten years has just passed since the United States Environmental Protection Agency (USEPA) introduced the 1622 and 1623 methods and used them to concentrate and detect the oocysts of Cryptosporidium and cysts of Giardia in water samples, they still need improvement. Pre-PCR processing procedures have been developed and they 
are still improved to remove or reduce the effects of PCR inhibitors. Currently, Cryptosporidium and Giardia by IMS prior to DNA extraction are standard procedures to eliminate or reduce substances that might be inhibitory to DNA amplification by PCR. These, however, has some limits and become impractical for organisms that have no IMS procedures or that cannot be cultured. Thus, the development of methods for direct extraction of PCR quality DNA is very significant for the detection of pathogens in environmental samples. A variety of polymerase chain reaction assays has been described for waterborne protozoans. The choice of a particular assay mainly depends on the amount of information carried by the genetic marker under analysis. Some assays can be used to identify the different species within a genus only, when others allowed to distinguish between isolates of the same species (genotypes), and some can be used for both aims. The main limitation of PCR is that it doesn't provide information on the viability and infectivity of the pathogen. Moreover, with the introduction of realtime PCR, quantitative aspect of the infection could be studied with exquisite sensitivity. This, for example, allows to detect carrier states, to determine the number of (oo)cysts present in a sample and to analyze quantitative aspects of gene expression during the various stages of the infection. In addition, the progress in molecular methods allows simultaneous detection of several parasites, however, they are not yet routinely used and need standardization.

\section{ACKNOWLEDGEMENTS}

his review was supported in part by the Ministry of Science and Higher Education, grant no. N N404 248635.

\section{REFERENCES}

Ali I.K., Hossain M.B., Roy S., Ayeh-Kumi P.F., Petri W.A. Jr, HAQUe R. \& CALRK C.G. Entamoeba moshkovskii infections in children, Bangladesh. Emerging Infectious Diseases, 2003, 9 (5), 580-584.

Amar C.F., Dear P.H. \& Mclauchlin J. Detection and genotyping by real-time PCR/RFLP analyses of Giardia duodenalis from human faeces. Journal of Medical Microbiology, 2003, 52 (8), 681-683.

Barbosa J., Costa-de-Oliveira S., Rodrigues A.G. \& Pina-Vaz C. Optimization of a flow cytometry protocol for detection and viability assessment of Giardia lamblia. Travel Medicine and Infectious Diseases, 2008, 6 (4), 234-239.

Braid M.D., Daniels L.M. \& KitTs C.L. Removal of PCR inhibitors from soil DNA by chemical flocculation. Journal of Microbiological Methods, 2003, 52 (3), 389-393.
Bouzid M., Steverding D. \& Tyler K.M. Detection and surveillance of waterborne protozoan parasites. Current Opinion in Biotechnology, 2008, 19 (3), 302-306.

Bruzzoniti M.C., Sarzanini C. \& Mentasti E. Preconcentration of contaminants in water analysis. Journal of Chromatography, 2000, 902 (1), 289-309.

Caccio S.M. \& Ryan U. Molecular epidemiology of giardiasis. Molecular and Biochemical Parasitology, 2008, 160 (2), 7580.

Da Silva A.J., Bornay-Llinares F.J., Moura I.N., Slemenda S.B., Tuttle J.L. \& PieniazeK N.J. Fast and reliable extraction of protozoan parasite DNA from fecal specimens. Molecular Diagnosis, 1999, 4 (1), 57-64.

FAYER R. Cryptosporidium: a water-borne zoonotic parasite. Veterinary Parasitology, 2004, 126 (1-2), 37-56.

Fontaine M. \& Guillot E. An immunomagnetic separationreal-time PCR method for quantification of Cryptosporidium parvum in water samples. Journal of Microbiological Methods, 2003, 54 (1), 29-36.

Francy D.S., Simmons III O.D., Ware M.W., Granger E.J., Sobsey M.D. \& Schaefer III F.W. Effects of seeding procedures and water quality on recovery of Cryptosporidium oocysts from stream water by using U.S. environmental protection agency method 1623. Applied and Environmental Microbiology, 2004, 70 (7), 4118-4128.

Furness B.W., Beach M.J. \& RoberTs J.M. Giardiasis surveillance-United States, 1992-1997. Morbidity and Mortality Weekly Report, 2000, 49 (7), 1-13.

Goldschmidt P., Degorge S., Saint-Jean C., Year H., Zekhnini F., Batellier L., Laroche L. \& Chaumeil C. Resistance of Acanthamoeba to classic DNA extraction methods used for the diagnosis of corneal infections. British Journal of Ophthalmology, 2008, 92 (1), 112-115.

GraCZYK T.K. \& CONN D.B. Molecular markers and sentinel organisms for environmental monitoring. Parasite, 2008, 15 (3), 458-462.

Guy R.A., Payment P., Krull U.J. \& Horgen P.A. Real-Time PCR for Quantification of Giardia and Cryptosporidium in Environmental Water Samples and Sewage. Applied and Environmental Microbiology, 2003, 69 (9), 5178-5185.

Haque R., Roy S., Siddique A., Mondal U., Rahman S.M.M., Mondal D., Houpt E. \& Petri W.A. Jr. Multiplex Real-Time PCR assay for detection of Entamoeba histolytica, Giardia intestinalis, and Cryptosporidium spp. American Journal of Tropical Medicine and Hygiene, 2007, 74 (4), 713-717.

Jiang J., Alderisio K.A., Singh A. \& Xiao L. Development of procedures for direct extraction of Cryptosporidium DNA from water concentrates and for relief of PCR inhibitors. Applied and Environmental Microbiology, 2005, 71 (3), 1135-1141.

Johnson D.W., Pieniazek N.J., Griffin D.W., Misener L. \& Rose J.B. Development of a PCR protocol for sensitive detection of Cryptosporidium oocysts in water samples. Applied and Environmental Microbiology, 1995, 61 (11), 3849-3855. 
Khatrnar K. \& Parija S.C. A novel nested multiplex polymerase chain reaction (PCR) assay for differential detection of Entamoeba histolytica, E. moshkovskii and E. dispar DNA in stool samples. BMC Microbiology, 2007, 7, 47.

KLEIN D. Quantification using real-time PCR technology: applications and limitations. Trends in Molecular Medicine, 2002, 8 (6), 257-260

Kramer F., Vollrath T., Schnieder T. \& Epe C. Improved detection of endoparasite DNA in soil sample PCR by the use of anti-inhibitory substances. Veterinary Parasitology, 2002, 108 (3), 217-226.

LEAV B.A., Mackay M. \& WaRD H.D. Cryptosporidium species: new insights and old challenges clinical infectious diseases. Clinical Infectious Diseases, 2003, 36 (7), 903-908.

Loge F.J., Thompson D.E. \& Call D.R. PCR detection of specific pathogens in water: a risk-based analysis. Environmental Science \& Technology, 2002, 36 (12), 2754-2759.

Lowery C.J., Nugent P., Moore J.E., Millar B.C., Xiru X. \& DOOLEY J.S. PCR-IMS detection and molecular typing of Cryptosporidium parvum recovered from a recreational river source and an associated mussel (Mytilus edulis) bed in Northern Ireland. Epidemiology and Infection, 2001, 127 (3), 545-553.

Monis P.T., Andrews R.H., Mayrhofer G. \& Ey P.L. Molecular systematics of the parasitic protozoan Giardia intestinalis. Molecular Biology and Evolution, 1999, 16 (9), 1135-1144.

Ng C.T., Gilchrist C.A., Lane A., Roy S., Haque R. \& Houpt E.R. Multiplex Real-Time PCR assay using scorpion probes and DNA capture for genotype-specific detection of Giardia lamblia on fecal samples. Journal of Clinical Microbiology, 2005, 43 (3), 1256-1260.

Nugent P., Moore J.E., Millar B.C., Xiru X. \& Dooley J.S. PCR-IMS detection and molecular typing of Cryptosporidium parvum recovered from a recreational river source and an associated mussel (Mytilus edulis) bed in Northern Ireland. Epidemiology and Infection, 2001, 127 (3), 545553.

PARIJA S.C. \& KhaIRNAR K. Entamoeba moshkovskii and Entamoeba dispar-associated infections in Pondicherry, India. Journal of Health, Population and Nutrition, 2005, 23 (3), 292-295.

RAMIREZ N.E. \& SREEVATSAN S. Development of a sensitive detection system for Cryptosporidium in environmental samples. Veterinary Parasitology, 2006, 136 (3-4), 201-213.

Roy S., Kabir M., Mondal D., Ali I.K.M., Petri W.A. JR \& HaQue R. Real-time PCR assay for the diagnosis of Entamoeba bistolytica infection. Journal of Clinical Microbio$\log$, 2005, 43 (5), 2168-2172.

Ruecker N.J., Braithwaite S.L., Topp E., Edge T., Lapen D.R., Wilkes G., Robertson W., Medeiros D., Sensen C.W. \& NeuMANN N.F. Tracking Host Sources of Cryptosporidium spp. in raw water for improved health risk assessment. Applied Environmental Microbiology, 2007, 73 (12), 3945-3957.

ShaW N.J., Villegas L.F., Eldred B.J., Gaynor D.H., WARden P.S. \& PePICH B.V. Modification to EPA Method 1623 to address a unique seasonal matrix effect encountered in some U.S. source waters. Journal of Microbiological Methods 2008, 75 (3), 445-448.
TeBbe C.C. \& VAHJEN W. Interference of humic acids and DNA extracted directly from soil in detection and transformation of recombinant DNA from bacteria and a yeast. Applied and Environmental Microbiology, 1993, 59 (8), 2657-2665.

U.S. Environmental Protection Agency. Method 1622-Cryptosporidium and Giardia in water by filtration/IMS/FA. U.S. Environmental Protection Agency publication no. 821/R-01026. U.S. Environmental Protection Agency, Washington, D.C., 2001.

U.S. Environmental Protection Agency. Method 1623-Cryptosporidium and Giardia in water by filtration/IMS/FA. U.S. Environmental Protection Agency publication no. 821/R-01025. U.S. Environmental Protection Agency, Washington, D.C., 2001.

Verweij J.J., Blange R.A., Templeton K., Schinkel J., Brienen E.A.T., van RoOYen M.A.A., VAN LeISHOUt L. \& POLERMan A.M. Simulatnous detection of Entamoeba histolytica, Giardia lamblia, and Cryptosporidium parvum in fecal samples using multiplex real-time PCR. Journal of Clinical Microbiology, 2004, 42 (3), 1220-1223.

WARE M.W., Wymer L., Lindquist H.D. \& SChaEFER III F.W. Evaluation of an alternative IMS dissociation procedure for use with method 1622: detection of Cryptosporidium in water. Journal of Microbiological Methods, 2003, 55 (3), 575-583.

WeINTRAub J.M. Improving Cryptosporidium testing methods: a public health perspective. Journal of Water Health, 2006, 4 (1), 23-26.

Yang W., Chen P., Villegas E.N., Landy R.B., Kanetsky C., Cama V., Dearen T., Schultz C.L., Orndorff K.G., Prelewicz G.J., Brown M.H., Young K.R. \& XiaO L. Cryptosporidium source tracking in the Potomac River Watershed. Applied and Environmental Microbiology, 2008, 74 (21), 6495-6504.

Widmer K.W., SRIKumar D. \& Pillai S.D. Use of artificial neural networks to accurately identify Cryptosporidium oocyst and Giardia cyst images. Applied Environmental Microbiology, 2005, 71 (1), 80-84.

WILSON I.G. Inhibition and facilitation of nucleic acid amplification. Applied Environmental Microbiology, 1997, 63 (10), 3741-3751.

Wohlsen T., Bates J., Gray B. \& Katouli M. Evaluation of five membrane filtration methods for recovery of Cryptosporidium and Giardia isolates from water samples. Applied Environmental Microbiology, 2004, 70 (4), 2318-2322.

XiaO L., Lal A.A., Jiang J. Detection and differentiation of Cryptosporidium oocysts in water by PCR-RFLP. Methods in Molecular Biology, 2004, 268, 163-176.

Reçu le 2 mars 2009 Accepté le 18 juin 2009 